\title{
Kan diplomstuderende læse en peer-reviewet artikel i den første uge?
}

\author{
Anker Helms Jørgensen, lektor ved IT-Universitetet i København.
}

\section{Reviewet artikel}

Peer-reviewede artikler er det akademiske guld inden for de empiriske videnskaber. På trods af deres specialiserede, fagspecifikke indhold har de undervisningsmæssigt potentiale til at indvie de studerende i universitetets etos. Hvornår kan studerende læse sådanne artikler? I den allerførste uge på universitetet? Dette har jeg undersøgt i et kursus for diplomstuderende, hvoraf 2/3 aldrig har taget et kursus på et universitet. De arbejder med en frivillig øvelse i første uge: de læser en peer-reviewet artikel (Monk et al., 2004), skriver et abstract af den og giver hinanden feedback. Artiklens emne er alment: Hvorfor mobiltelefoner er generende $i$ det offentlige rum? Den er velskrevet og giver et godt billede af, hvordan forskere arbejder. Artiklen er ledsaget af stilladsering med forklaringer, spørgsmål og svar. Undersøgelsen omfattede 94 studerende. Resultatet viser, at $89 \%$ skrev et abstract, 96\% fandt brugen i første uge acceptabel og $100 \%$ mente, at øvelsen skulle gentages $i$ næste semester. De studerende værdsatte artiklens autenticitet; de fandt det nyttigt og udfordrende at skrive tidligt; skrivningen fik dem til at tænke. Alt $i$ alt var det en succesoplevelse, som gav dem blod på tanden. Det er således klart, at diplomstuderende kan læse en peer-reviewet artikel i den første uge med udbytte.

\section{Indledning: Hvornår kan studerende læse en peer-reviewet artikel?}

Forskning og forskningsbaseret undervisning er universiteternes adelsmærker. Universiteterne er under forandring i kraft af bevægelsen fra eliteuniversitet til masseuniversitet (Christiansen et al., 2013). Dette kan have konsekvenser for den forskningsbaserede undervisning, der findes i en række former: fokus på forskningsresultater/proces og de studerende som tilhørere/deltagere. Bevægelsen kan også manifestere sig mere konkret ved valg af litteratur. I de empiriske videnskaber har tertiær litteratur, som lærebøger, en åbenlys plads i undervisningen, specielt i de første semestre. De giver overblik, de er velskrevne og veldisponerede. De bedste af dem er revideret flere gange, hvorved kernen af et fagområde fremstår klart og koncist. En del af dem præsenterer også et direkte kig på forskningen gennem uddrag af eller omtale af peer-reviewede artikler eller interviews med anerkendte forskere (se fx Rogers, Preece \& Sharp, 2011). I modsætning hertil fremstår primær litteratur som peer-reviewede artikler som det akademiske guld i de empiriske videnskaber. De er korte og stærkt fagligt fokuserede. De er ofte velskrevne, da de har været igennem 
omfattende revisioner. En del af dem illustrerer direkte, hvordan forskere arbejder: fra idé, baggrund og motivation over metode til fortolkning, resultater, diskussion og konklusion. På trods af deres specialiserede, fagspecifikke indhold har de undervisningsmæssigt potentiale til at indvie de studerende i universitetets etos. De kan derved afmontere noget af andægtigheden over for forskningen, og de kan give studerende et kig ind i forskerens værksted og derved give mulighed for at se, hvordan der arbejdes og kommunikeres. Endelig eksemplificerer de peer-reviewede artikler den skriftlige akademiske genre; en struktur, som de studerende kan læne sig op ad senere.

Spørgsmålet er, hvornår studerende kan læse sådanne peer-reviewede artikler? Allerede i den første uge i deres første semester på et universitet? Vanskelighederne er åbenlyse: meget afgrænsede emner, specialiserede teorier, fagspecifikke metoder, indforstået terminologi og fremmedartede genrekonventioner. Og for de studerende kan en negativ tidlig læringserfaring være katastrofal, specielt for de med beskeden akademisk baggrund (Demirel, 2011).

\section{Hvad siger litteraturen?}

Litteraturen synes ikke at give noget svar på, hvornår og under hvilke omstændigheder studerende kan læse peer-reviewede artikler. I den substanstielle bog Academic Writing for Graduate Students falder en to-siders artikel om flagermus med ledsagende spørgsmål i øjnene (Swales \& Feak, 2004, s. 218). På samme måde præsenterer Yakhontova (2010) en fiktiv, to-siders artikel om sammenhængen mellem studerendes ernæring og eksamensresultater. Denne artikel anvendes af Jørgensen og Rienecker $(2009$, s. 143) til at præsentere den akademiske genre mht. metakommunikation, anvendelse af teori, og præsentation af resultater. Demirel (2011) anbefaler, at studerende analyserer videnskabelige artikler for at reducere deres usikkerhed ved skrivning og revision. Hvor relevante disse tiltag og anbefalinger end måtte være, præsenterer disse forfattere hverken erfaringer om brugen af sådanne artikler eller hvornår i studiet, de kan anvendes.

En meget relevant undersøgelse er udført af John Bean (2011). Udgangspunktet var "At what point in their undergraduate careers should students be asked to read primary scientific literature?" Han fandt, at de studerende godt kunne læse peerreviewede artikler - omend uden "rhetorical sophistication". Som de andre forfattere forholder John Bean sig heller ikke til det specifikke tidspunkt.

På denne baggrund har jeg undersøgt, om studerende kan læse en peer-reviewet artikel (Monk et al., 2004) i den første uge. Dette er er sket i mit eget kursus Introducerende Akademisk Projekt på IT-Universitetet, hvor deltagerne er diplomstuderende med en professionel IT-baggrund. For de flestes vedkommende er dette kursus deres første møde med et universitet. At undersøge forskningsspørgsmålet i mit eget 
kursus er på ingen måde ideelt, hverken metodisk eller videnskabsteoretisk. Det burde som minimum ske i en anden lærers kursus. Det var desværre ikke realistisk, da det ville indebære en betydelig forandring af et eksisterende kursusforløb. Den beskedne dækning i litteraturen betød, at min tilgang blev meget eksplorativ. Denne tilgang minder om paradigmet aktionsforskning (Argyris et al., 1985), hvor handling, refleksion, teori og praksis foldes ud under løsning af praktiske problemer. I det følgende præsenterer jeg først konteksten for undersøgelsen og overvejelserne om materialerne. Derefter følger en beskrivelse af forløbet og resultaterne efterfulgt af en diskussion og konklusion.

\section{Den uddannelsesmæssige kontekst}

IT-Universitetet udbyder en diplomuddannelse for it-professionelle. De er typisk mellem 25 og 55 år og arbejder bl.a. som projektledere, systemudviklere og grafiske designere. De har ingen eller kun en beskeden akademisk baggrund. Nogle få har kun taget 9. eller 10. klasse, langt de fleste har en studentereksamen og en kort videregående uddannelse som programmør eller tekniker, mens nogle få har gennemført et eller to år på et universitet. Cirka $2 / 3$ af dem har aldrig taget et kursus på et universitet $(69.8 \%)$.

De diplomstuderende har en tendens til at vælge hands-on kurser som projektledelse, grafisk design eller PHP-programmering. IT-Universitetet ønsker imidlertid også, at de studerende tidligt lærer en central akademisk færdighed: at gennemføre et forskningsprojekt. Det sker i kurset ${ }^{1}$ Introducerende Akademisk Projekt. Det er organiseret $\mathrm{i}$ to dele. I første del på 5 uger sættes de studerende i gang, socialiseres, vælger emner og danner grupper. I anden del på 10 uger gennemfører de studerende et projektarbejde i grupper under vejledning med et selvvalgt emne - næsten altid en empirisk undersøgelse. Kurset følges typisk af 30 studerende. De fleste af dem er fremmede over for den akademiske dagsorden og usikre på, om de kan håndtere rollen som studerende.

Så spørgsmålet er: Hvordan kan jeg inden for disse rammer undersøge, om de diplomstuderende kan arbejde med en peer-reviewet artikel med udbytte i den første uge?

\footnotetext{
${ }^{1}$ Kurset er egentlig en såkaldt 'projektklynge', dvs. en række beslægtede, men selvstændige projekter.
} 


\section{Metode}

I dette afsnit beskrives overvejelser om tilgangen, valg af artikel, stilladsering og det konkrete forløb ledsaget af den teoretiske forankring.

Overvejelser om forsknings- og undervisningsnexus

Helt overordnet skønnede jeg, at det var afgørende, at øvelsen balancerede mellem at være udfordrende på grund af de studerendes professionelle baggrund og gennemførlig på grund af deres beskedne akademiske baggrund. Da de studerende skal gennemføre et forskningsprojekt, er det relevant at inddrage overvejelser om forsknings- og undervisningsnexus. Disse er baserede på Healeys (2005) model. Denne model omfatter to dimensioner: studerende som deltagere eller tilhørere og undervisningens fokus på forskningsresultater eller på forskningsproblemer/processer.

Spørgsmålet er, hvordan der i første uge kan skabes et afsæt til resten af semesteret. I kursets hoveddel på 10 uger - anden del af semesteret - gennemfører de studerende et gruppeprojekt som deltagere i en forskningsproces på et selvvalgt forskningsproblem. Disse projekter har selvsagt forskningskarakter i det små, men de studerende agerer i betydelig grad i ukendt territorium på grund af de studerendes valg af aktuelle, it-specifikke emner, som ofte ikke er særlig udfoldede i litteraturen.

Hvordan skal første del på 5 uger lægge op til anden del? Jeg valgte i første uge at lade de studerende være tilhørere gennem min introduktion til den akademiske genre og artiklen, arbejdet med artiklen med fokus på både forskningsmetode og resultat, og skrivning af et abstract som en slags emulerede deltagere; flere af de studerende fandt det nyttigt, at de i øvelsen med at skrive abstractet med fordel kunne opfatte sig selv som artiklens forfattere. Dette mønster gentages i anden uge, hvor de læser en god rapport fra et tidligere semester, skriver et abstract og vurderer rapporten: skriver tre gode ting, og tre ting, der kunne være bedre. Herved vokser de ud af tilhørerrollen ved at være reviewere. I tredie uge gennemfører de studerende en beskeden forskningsproces som deltagere: de laver en lille empirisk undersøgelse om et selvvalgt emne og skriver en A4-side om det i IMRD-formatet (Introduction, Method, Results, Discussion). Forløbet gennem de første tre uger bringer således de studerende trinvis gennem formerne forskningsledet, forskningsstøttet og forskningsbaseret (Dohn \& Dolin, 2013).

Denne tilgang med fokus på handling i den teoretisk orienterede universitetsverden er ydermere funderet i Tynjälä et al. (2003) gennem at skabe balance mellem den typiske læringsform på universiteterne, der er individuelt orienteret, mental og symbolmanipulerende, og den typiske arbejdsorienterede læring, der er social, fysisk, kontekstualiseret og objektorienteret. 
Valg af artikel

Valget af artiklen - "Why are mobile phones annoying?" (Monk et al., 2004) - er meget afgørende. Den opfyldte mine krav: Den handler om et alment og interessant emne; man kan følge problemfeltet hele vejen, da artiklen ikke fortaber sig i en abstrakt, akademisk diskurs; den er repræsentativ for den akademiske genre: original, substantiel, velskrevet og veldisponeret; den er disponeret efter den klassiske IMRDmodel; den synliggør forskningsprocessen; resultatet er interessant og ikketrivielt; den er publiceret i det anerkendte tidsskrift Behavior and Information Technology med impact factor på 0.84; og artiklen er rimeligt citeret (Google Scholar count 90 pr. november 2013). Artiklen er på 9 sider og handler om gener ved snak i mobiltelefon $i$ det offentlige rum. Den beskriver et eksperiment, hvor ventende på en busstation eller rejsende $i$ et tog blev udsat for samtaler face-to-face eller i mobiltelefon med normal eller høj lydstyrke; dette er et $2 * 2 * 2$ between-subjects eksperimentelt design. De rejsende blev derefter interviewet om gener ved samtalerne. Resultaterne er meget overbevisende og stort set statistisk signifikante.

Som nævnt er artiklen struktureret efter IMRD-formatet. Dette format har ikke alene været undersøgt nøje (fx Swales, 1990), men også problematiseret, da det ikke afspejler forskningsprocesen (Burrough-Boenisch, 1999). Men på trods af dets svagheder har jeg valgt det på grund af dets enkelhed, dets forankring i naturvidenskab (North, 2005) i kraft af dets stærke fokus på struktur og muligheden for transfer til gruppeprojekterne.

\section{Stilladsering}

Valget af en peer-reviewet artikel skulle nok sikre, at de studerende blev udfordret i tilstrækkelig grad. Og af hensyn til gennemførligheden valgte jeg at stilladsere artiklen, så de studerende havde mulighed for at følge en vej gennem øvelsen, hvis de fandt det alt for fremmed og svært. Jeg identificerede først 44 "interessante" steder i artiklen med retoriske, strukturelle, metodemæssige og teoretiske facetter, fx om titlen er informativ og fængende, om brugen af litteratur, konventioner for henvisninger, beskrivelse af metoder og præsentation, fortolkning og diskussion af resultater. Disse steder markerede jeg i marginen med $\aleph, \mathfrak{I}, \mathfrak{R} \ldots$, se figur 1 :

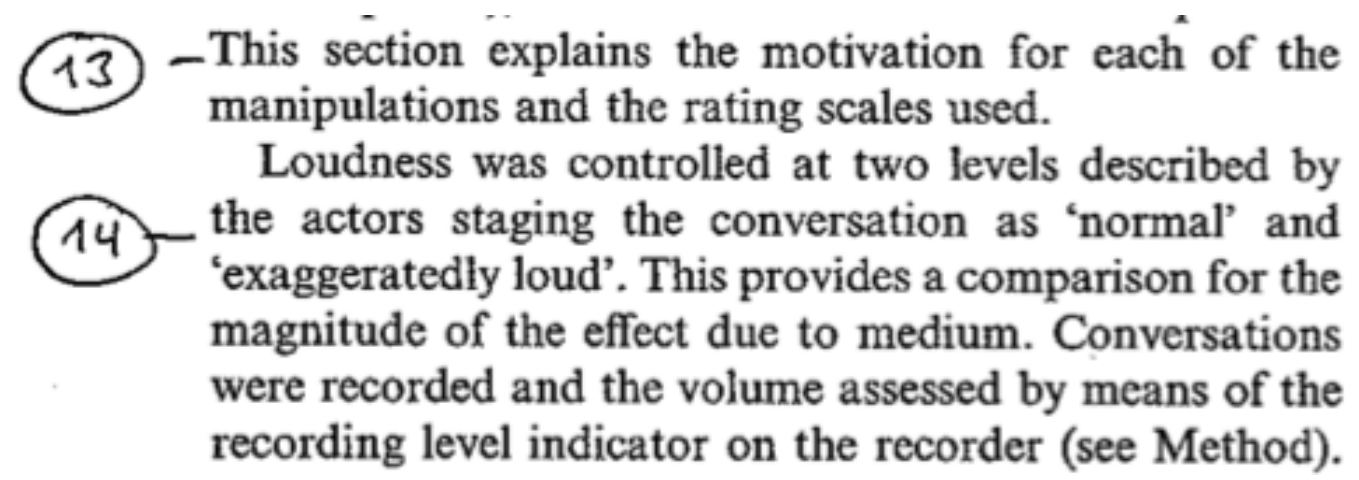

Figur 1: To interessante steder $i$ artiklen. 
De to steder i figur 1 vedrører metakommunikation: 13) "God metakommunikation: Beskriver hvad der sker $i$ det følgende" og metodebeskrivelse: 14) "Dette afsnit beskriver $i$ detaljer de tre uafhrngige variable..." i alt 6 liniers beskrivelse af det eksperimentelle design. Med udgangspunkt heri udarbejdede jeg et sæt skriftligt materiale ${ }^{2}$ :

- En introduktion, der motiverer øvelsen (1.5 side)

- Forklaringer til artiklen, fx hvad er et $2 * 2 * 2$ between-subjects design (3.5 side).

- Atten spørgsmål primært til genre og struktur, fx hvor i artiklen formålet med arbejdet præsenteres ( 2 sider).

- Ni spørgsmål primært til indhold, fx om artiklen faktisk leverer det, som titlen lover (1.5 side).

- Artiklen i to udgaver: en med angivelse af de 44 steder og en "nøgen" uden.

Af hensyn til opgavens gennemførlighed valgte jeg at give de studerende mulighed for at se svarene på spørgsmålene. De kunne således tjekke deres svar mod mine og derved få hurtig, kontekstualiseret feedback. Svarene, som er begrundet og uddybet, er anbragt i fodnoter, så de studerende ikke lige kommer til at se svaret. De studerende kan således enten anvende en enkel "følg de 44 steder-strategi" eller en mere ambitiøs strategi med den "nøgne" artikel.

I overensstemmelse med god forskningsskik testede jeg øvelsen med tre frivillige diplomstuderende. De fandt den nyttig og gennemførlig og foreslog mindre ændringer. Derefter bad jeg fem kolleger om at vurdere den. De var meget positive og understregede relevansen af den slags materiale.

\section{Undervisningsforløbet i første uge}

Som nævnt består kursets første del af fem undervisningsgange for at skabe afsæt for gruppeprojekterne. Den første gang introducerer jeg den akademiske genre - "en dokumentation af .... undersøgelse ... problem ... teorier/metoder ... overbevise..." gennem en øvelse (Rienecker og Jørgensen, 2012, s. 21), IMRD-formatet, øvelsen og artiklen. Jeg lægger vægt på skrivning som et stærkt akademisk redskab til at dokumentere, synliggøre og formidle et produkt og som redskab til at stimulere tænkning og social interaktion.

I introduktionen af øvelsen - som i øvrigt er frivillig - understreger jeg, at en tekst kan læses på forskellige måder: overfladisk eller dybt. Som John Bean (2011) betegner det: som en fugl (der læser for struktur og overblik), en myre (der gransker detaljer) eller en flyvende myre (der skifter mellem de to). I øvelsen skal de studerende først læse instruktionen og derefter artiklen som en fugl eller en (flyvende) myre. Dernæst skal de besvare de to sæt spørgsmål. For at skabe bevægelse fra tilhørerrol-

2 Materialerne kan downloades på: http://ankervejleder.wordpress.com/2013/09/09/ovelsen-medartiklen-om-gener-ved-mobiltelefoner. 
len mod deltagerrollen (Healey, 2005) skriver de ydermere et abstract på 10-15 linier; dette uploades før anden undervisningsgang. At de studerende skriver abstracts er i overensstemmelse med Lizzas (2007) pointe: "reading is more rewarding if you have a product to show" og Devets (2011) anbefaling af at have et publikum for det skrevne - som ikke blot er læreren.

Til anden undervisningsgang medbringer jeg prints af deres abstracts, og de studerende giver hinanden feedback med Tekstfeedback-spillet (Jensen og Jensen, 2011). Spillet giver en ramme og en struktur i en sensitiv situation, som de studerende er meget usikre på: Hvor meget kan man som begynder tillade sig at sige om et emne, som man stort set ikke ved noget om, til de andre studerende? Peer-feedback'en understøtter også sammenbindingen af det akademiske og det sociale liv, idet de studerende lærer hinanden at kende og oplever hinanden i følsomme situationer (Stieha, 2010). Tilgangen er også i overensstemmelse med Demirels (2011) anbefalinger om at reducere de studerendes usikkerhed ved at give dem klare instruktioner, lade dem samarbejde og analysere hinandens arbejde.

De studerende er usikre som reviewere og derfor meget interesserede i min feedback. Den får de i skriftlig form på trods af vægtige indikationer i litteraturen om, at de studerendes egen feedback er mere nyttig (Cho \& McArthur, 2011). Det ville også være en overvejelse værd at lade de studerende revidere deres abstracts på basis af feedback'en, jf. Demirels (2011) multiple draft-tilgang. Men det fravælger jeg og lægger i stedet vægt på skrivning som et redskab til tænkning (Dysthe, 2011). Dysthes forslag er begrundet empirisk, idet hun fandt en meget stor forskel på omfanget og dybden af lærernes feedback og de studerendes faktiske brug af den. Jeg skønnede således, at det var mere udbytterigt for de studerende at skrive et nyt abstract $\mathrm{i}$ anden uge.

For at fremme den pragmatiske tilgang har jeg fravalgt at anvende litteratur om genrer og abstracts, (se fx Swales, 1990; Swales og Feak, 2004) for i stedet at skabe praksisorienteret læring baseret på de studerendes egen skrivning og peer-feedback.

På trods af, at min kernefaglighed er digitalt design og hverken retorik eller pædagogik, har jeg valgt selv at optræde som "skrivelærer" i modsætning til at involvere en medarbejder fra et skrivecenter. Dette er i overensstemmelse med Devets (2011) anbefaling om, at den faglige lærer står for skrivningen, da det bedst "aligner" skriveaktiviteten med læringsmålene. 
Artiklen om mobiltelefonerne indeholder et abstract, og læseren kan med rette spørge, hvorfor jeg beder de studerende om at skrive et selv? Udover den pædagogiske pointe om at skrive, er der en indholdsmæssig: artiklens abstract er ikke godt. Det indledes lige på uden baggrund og problem: "Sixty four members of the public were exposed to the same staged conversation either waiting in a bus station or travelling on a train. ..."

\section{Resultater}

I denne undersøgelse indgår data fra 94 studerende i semestrene forår 2012 til forår 2013, hvor øvelsen har fundet en helt stabil form. Resultaterne omfatter de studerendes deltagelse, kvaliteten af deres abstracts og deres holdning til øvelsen.

De studerendes deltagelse

Af de 94 studerende skrev de 84 et abstract (89.4\%). De fleste arbejdede med spørgsmålene om genre/struktur (65.0\%) og med indholdsspørgsmålene (60.0\%). En majoritet anvendte artiklen med angivelser af de 44 steder (75.0\%), men ganske mange anvendte (også) den "nøgne" artikel (33.8\%). Givet at øvelsen er frivillig, synes disse tal at tyde på engagement $\mathrm{i}$ kurset og udbytte af øvelsen.

\section{Kvaliteten af de studerendes abstracts}

Jeg beder de studerende om at skrive et abstract på 10-15 linjer, men tendensen er mod længere abstracts: median 17, minimum 11 og maximum 25 linjer. Eftersom jeg primært anvender denne tidlige øvelse som introduktion til den akademiske etos, fokuserer jeg i undervisningen ikke på kvaliteten af deres abstracts. Men den er selvsagt ikke uvigtig. Typiske svagheder er mangel på rød tråd, bratte overgange, udeladelse af vigtige pointer, fremhævelse af unødige detaljer, upræcise beskrivelser og sprogfejl. Eksempler på alvorlige misforståelser er sjældne. Det tyder på, at de studerende ikke alene læser for struktur og genre, men også for indhold. Som nævnt findes der et abstract i artiklen, men jeg har ikke en eneste gang set en studenterbesvarelse, der fremstår som en revision af dette, endsige som et plagiat. 
De studerendes holdninger

De studerende udfylder et spørgeskema om øvelsen i slutningen af anden undervisningsgang. Skemaet omfatter lukkede spørgsmål og frie kommentarer. Jeg har fået i alt 82 svar. Det er fra alle de studerende, der deltog i undervisningen anden gang.

- De studerende fandt øvelsens relevans ganske høj: Ikke relevant (0\%), noget relevant $(6.3 \%)$, meget relevant $(74.7 \%)$ og extrem relevant $(19.0 \%)$.

- De vurderede sværhedsgraden således: Urimelig svær $(0.0 \%)$, ret svær (13.9\%), OK (78.5\%), ret let (7.6\%) og meget let $(0 \%)$.

- Givet at øvelsen er ret ambitiøs, var jeg også interesseret i tidsforbruget: Gennemsnittet var 4.5 time, men variationen var stor: fra 2-3 timer til mere end 10 timer. De fleste (87.5\%) har dog brugt 2-6 timer og dermed nok - som tiltænkt - skiftet mellem at læse som en fugl og som en (flyvende) myre (Bean, 2011).

- Den mest kritiske ting er placeringen i første uge. De studerendes opfattelse var: Skulle placeres meget senere $(0 \%)$, noget senere $(3.8 \%)$, og det var OK (96.3\%).

- De studerendes opfattelse af, hvor representativ artiklen er for den akademiske genre: Et dårligt indtryk (2.6\%), et rimeligt indtryk (29.5\%), et godt indtryk $(59.0 \%)$ og et meget godt indtryk (9.0\%). Kun 68.0\% finder, at artiklen giver et godt eller meget godt indtryk. Dette tal er ikke særlig højt, men det synes qua den store deltagelse ikke at være gået ud over øvelsens troværdighed og de studerendes engagement.

- Endelig spørger jeg, om artiklen skal anvendes på kurset i næste semester. Svarene er: ja (87.2\%), ja hvis den forbedres (12.8\%) og nej $(0 \%)$. Forbedringsforslagene handler om en nyere artikel og en artikel på dansk.

\section{De studerendes frie kommentarer}

De væsentlige frie kommentarer fra de studerendes var: værdsættelse af artiklens autenticitet; artiklen er ikke perfekt, så man kan finde svagheder og foreslå forbedringer; det var godt at komme i gang med at skrive tidligt; det ledsagende materiale var godt; peer-review-metoden er nyttig, også uden for universitetet; at skrive stimulerede tænkning; og øvelsen var en succesoplevelse, og den gav blod på tanden. Det er således klart, at øvelsen har været udbytterig både med hensyn til det indholdsmæssige, det sociale og det at indvie de studerende i universitetets etos. Balancen i øvelsen mellem at være udfordrende og gennemførlig blev illustreret af en studerende, der bemærkede, at først oplevede hun øvelsen angstprovokerende, men efterhånden kom læselysten til andre artikler, efterhånden som hun fik arbejdet sig ind i den. 


\section{Diskussion}

Min undersøgelse af spørgsmålet, om diplomstuderende kan læse en peer-reviewet artikel i den første uge; har været eksplorativ og er sket på mit eget kursus. Derfor kan der rejses en række indvendinger mod arbejdet og dets resultater. Først og fremmest har jeg hele tre roller i dette forløb. For det første har jeg skabt forløbet og vil selvsagt gerne se det som en succes. For det andet er magtforholdet mellem de studerende og jeg meget ulige, idet jeg er underviser for alle de diplomstuderende $i$ de første fem uger og er vejleder (og eksaminator) for 2-4 af de ca. 10 grupper i resten af semesteret. For det tredje forestår jeg undersøgelsen af forskningsspørgsmålet. Disse tre roller påvirker uundgåeligt både de studerende og jeg selv. De studerende fornemmer, hvad jeg ønsker at høre, og jeg er tilbøjelig til at formulere spørgsmål og fortolke svarene mere positivt - på trods af mine opfordringer til dem om at være ærlige og mine egne forsøg på at være selvkritisk.

Valget af artikel spiller sandsynligvis en helt afgørende rolle. Mit skøn er, at artiklens almene emne, dens metodiske og fremstillingsmæssige klarhed og det skarpe kig ind i forskerens værksted er afgørende. Artiklen udmærker sig ved, at selve problemstillingen, som alle kan relatere sig til, aldrig drukner i en "ren" akademisk diskurs. Den omfattende stilladsering har også spillet en væsentlig rolle - som indikeret af de studerendes svar. Det har givetvis også stor betydning, at de diplomstuderende er professionelle, så de forventer udfordringer og er parate til at honorere dem. De er meget motiverede, dels på grund af "uddannelsestørke" - for nogens vedkommende i årtier - og dels fordi de eller deres arbejdsgiver betaler for kurset (10.440 kr. pr. studerende).

\section{Konklusion}

Denne undersøgelses forskningsspørgsmål lød: Kan studerende læse en peerreviewet artikel i første uge i deres første semester på et universitet? Svaret synes at være et ja, da øvelsen har været udbytterig for de studerende både med hensyn til det indholdsmæssige, det sociale og indvielsen af de studerende i universitetets etos. En forudsætning er givetvis de klare instruktioner og den betydelige stilladsering. Undersøgelsen bekræfter klart John Beans (2011) resultater.

Undersøgelsen illustrerer ydermere en metode, der for mig at se kan overføres til andre kurser og fagområder. Afgørende er givetvis valg af tekst/artikel og stilladseringen - under hensyntagen til de studerendes baggrund og motivation.

Endelig har arbejdet haft stor betydning for min udvikling som universitetslærer. Ikke mindst har den massive deltagelse i skrivningen og de personlige kommentarer, fx dem om angstprovokation og læselyst, boostet mit engagement som underviser (French, 2011). 
Med en reference til Kirkegaards ord om at vove og miste, viste min indledende bekymring om øvelsens sværhedsgrad sig at være uberettiget og snarere betinget af en alt for begrænset opfattelse af de studerendes potentialer.

Alt i alt kan dette kig ind i forskerens værksted forskningsmæssigt opfattes som en indikation om, hvornår studerende kan læse en peer-reviewet artikel og undervisningsmæssigt måske tjene som inspiration for andre undervisere, både med hensyn til udvikling af nye undervisningsformer og i kraft af potentialet for selvudvikling som underviser.

Anker Helms Jørgensen er lektor i Digitalt Design ved IT-Universitetet i København. Han har gennem mange år forsket, undervist og været konsulent inden for området usability og interaktionsdesign. Inden sin ansæettelse på IT-Universitetet var han lektor i Psykologi ved Kobenhavns Universitet. Siden sin studietid har han vxret interesseret i pxdagogik og begyndte for ca. 10 år siden at arbejde mere systematisk med pædagogik og undervisningsudvikling med hans egen undervisningspraksis som drivkraft.

\section{Litteratur}

Argyris, C., Putnam, R, \& Smith, D. M. (1985). Action Science: Concepts, Methods, and Skills for Research and Intervention. San Francisco: Jossey-Bass.

Bean, J. (2011). Teaching rhetorical reading of primary scientific literature to first year undergraduates: a two-stage writing assignment. Proc. EATAW Conference, Limerick, Ireland, 29/6 - 1/7 2011, s. 100-101.

Burrough-Boenisch, J. (1999). International reading strategies for IMRD articles. Written Communication, 16(3), 296-316.

Cho, K. \& MacArthur, C. (2011). Learning by Reviewing. Journal of Educational Psychology, 103(1), 73-84.

Christiansen, F. V., Harboe, T., Horst, S., Krogh, L. \& Sarauw, L. L. (2013). Udviklingstendenser i universitetets rolle. I: Rienecker, L., Jørgensen, P. S., Dolin, J. \& Ingerslev, G. H. (red.). Universitetspædagogik. Frederiksberg: Samfundslitteratur, $17-41$.

Demirel, E. (2011). Take it step by step: Following a process approach to academic writing to overcome student anxiety. Journal of Academic Writing, 1(1), 222-227.

Devet, B. (2011). What teachers of Academic Writing can learn from the Wrtiting Center. Journal of Academic Writing, 1(1), 248-253.

Dohn, N. B. \& Dolin, J. (2013). Forskningsbaseret undervisning. I: Rienecker, L., Jørgensen, P. S., Dolin, J. \& Ingerslev, G. H. (red.). Universitetspædagogik. Frederiksberg: Samfundslitteratur, 43-64.

Dysthe, O. (2011). "What is the purpose of feedback when revision is not expected?" A case study of feedback quality and study design in a first year Master's programme. Journal of Academic Writing 1(1), 135-142.

French, A. (2011). "What am I expecting and why?" How can lecturers in Higher Ed- 
ucation begin to address writing development for their students? Journal of Academic Writing, 1(1), 228-238.

Healey, M. (2005). Linking research and teaching: Exploring disciplinary spaces and the role of inquiry based learning. I: R. Barnett (red.) Reshaping the university. New relations between research, scholarship and teaching. Berkshire: Open University Press, 67-78.

Jensen, T. W. \& Jensen, G. S. (2011). Engaging Students in the Peer-Review Process: Improved Peer-feedback on Texts Through the Conceptualization of a Board Game. Proc. ICER 2011, Madrid.

Jørgensen, P. S. \& Rienecker, L. (2009) Studiehåndbogen - for studiestartere på videregående uddannelser. Frederiksberg: Samfundslitteratur.

Lizza, M. (2007). Active Reading and the teaching of Writing. wwww.zeitschriftschreiben.eu 10.10. 2007.

Monk, A. M., Carroll, J., Parker, S. \& Blythe, M. (2004). Why are mobile phones annoying? Behaviour and Information Technology, 23(1), 33-41.

North, S. (2005). Different values, different skills? A comparison of essay writing by students from arts and science backgrounds. Studies in Higher Education, 30(5), 517-533.

Rienecker, L. \& Jørgensen, P. S. (2012). Den Gode Opgave. Frederiksberg: Samfundslitteratur.

Rogers, Y., Preece, J. \& Sharp, H. (2011). Interaction Design: Beyond Human-Computer Interaction. New York: Wiley.

Stieha, V. (2010). Expectations and experiences: the voice of a first-generation firstyear college student and the question of student persistence. International Journal of Qualitative Studies in Education, 23(2), 237-249.

Swales, J. M. (1990). Genre analysis: English in academic and research settings. Cambridge: Cambridge University Press, 1990.

Swales, J. M. \& Feak, C. B. (2004). Academic Writing for Graduate Students - essential tasks and skills. Ann Arbor: University of Michigan Press.

Tynjälä, P., Välimaa, J. \& Sarja, A. (2003). Pedagogical perspectives on the relationships between higher education and working life. Higher Education, 46, 147-166.

Yakhontova, T. (2010). Email communication, April 25, 2010. 